\title{
In vitro propagation of Alstroemeria using rhizome explants derived in vitro and in pot plants
}

\author{
Hamidoghli Yousef*, Bohloli Sahar and Hatamzadeh Abdollah \\ Horticultural Department, University of Guilan, Rasht, Iran. \\ Accepted 14 February, 2007
}

\begin{abstract}
Alstroemeria with beautiful and long shelf life of cut flower is one of the most important ornamental plants. This plant could propagate by splitting of the in vivo produced rhizomes but the propagation rate is rather low. In the present study, regeneration ability of plantlets was compared using in vitro and in vivo grown rhizome buds as explants. In vitro and in vivo grown rhizome buds were cultured on MS basal medium with 3 different compositions of growth regulators $(1,0.2 \mathrm{mg} \mathrm{l-1}$ NAA with $1 \mathrm{mg} \mathrm{l-1}$ BA and $0.2 \mathrm{mg} \mathrm{l}-1$ IAA with $1 \mathrm{mg} \mathrm{l}-1 \mathrm{BA})$. Cultures were incubated in $18 \pm 1^{\circ} \mathrm{C}$ at $16 \mathrm{~h}$ photoperiod. Four subculture of explants were done on the same fresh media with 3 weeks intervals. The results showed that in vivo rhizome bud produced the largest number of small rhizome and roots on medium containing $0.2 \mathrm{mg} \mathrm{l}-1 \mathrm{NAA}$ with $1 \mathrm{mg} \mathrm{l}-1 \mathrm{BA}$.
\end{abstract}

Key words: Alestroemeria, in vitro rhizogenesis, shoot proliferation.

\section{INTRODUCTION}

Alstroemeria is a rhizomatous monocot belonging to the family Alstroemeriaceae (Chiari and Bridgen, 2000). This plant is cultured in greenhouse for cut flower production and is propagated vegetatively by rhizome division. This kind of propagation is time consuming and contributes to the spread of virus diseases. Therefore in vitro propagation has been developed to accelerate the multiplication efficiency (Gabryszewska and Hempel, 1985; Hakkaart and Versluijs, 1988; Ven Zaayen et al., 1992; Bond and Alderson, 1993). Flower pedicels subapical, segments from the vegetative stem and rhizome buds of Alstroemeria were tested as initial explants. Of these, rhizome buds of Alstroemeria gave the best response as initial explants in in vitro conditions (Lin and Monette, 1987). However culture contamination using in vivo grown rhizome buds is a major problem that is difficult to overcome. Therefore use of rhizome bud explants taken from in vitro grown plants may solve this problem. At the present study, shoot proliferation, number of produced rhizome and root from each explant were evaluated.

\footnotetext{
${ }^{\star}$ Corresponding author. E-mail: hamidogli@yahoo.com.
}

\section{MATERIALS AND METHODS}

Plant materials

Rhizome buds of Alstroemeria cv. Jamaica were collected from plantlets $(\mathrm{O} 1)$ which were routinely propagated in vitro on MS basal medium (Murashige and Skoog, 1962) plus $2 \mathrm{mg} \mathrm{l}-1 \mathrm{BA}, 3 \%$ sucrose and $8 \%$ agar and pot plants $(\mathrm{O} 2)$ which were grown in greenhouse conditions. For surface sterilization of rhizome, those obtained from pot plants, ( $3 \mathrm{~cm}$ in length) were excised and washed thoroughly under running tap water for $10 \mathrm{~min}$. Thereafter, the rhizome explants sterilized by immersion for $35 \mathrm{~min}$ in $40 \%(\mathrm{v} / \mathrm{v})$ commercial bleach (containing $5.54 \%$ sodium hypochlorite) and finally the explants were washed 3 times in sterile distilled water for 3,5 and $10 \mathrm{~min}$, respectively. Single in vitro and in vivo rhizome bud were excised ( $3-7 \mathrm{~mm}$ ) using a sharp knife and cultured on MS basal medium with 3 different composition of growth regulators.

Culture media

The explants were planted in culture media as $\mathrm{M} 1(\mathrm{MS}+1 \mathrm{mg} \mathrm{l}-1$ $\mathrm{BA}+0.2 \mathrm{mg} \mathrm{l}-1 \mathrm{NAA}) \mathrm{Han}$ et al. (1994), M2 (MS + $1 \mathrm{mg} \mathrm{l}-1 \mathrm{BA}+1$ mg l-1 NAA) and $\mathrm{M} 3(\mathrm{MS}+1 \mathrm{mg} \mathrm{l}-1 \mathrm{BA}+0.2 \mathrm{mg} \mathrm{l}-1$ IAA) Podwyszynska et al. (1998), with $3 \%$ sucrose and solidified with $3 \%$ gel rite at pH 5.6 in $15 \mathrm{~cm}$ test tubes. 
Table 1. Effects of culture media and rhizome types on number of shoots, rhizomes and roots.

\begin{tabular}{|l|c|c|c|}
\hline \multicolumn{1}{|c|}{ Traits } & Shoot (number) & Rhizome (number) & Root (number) \\
\hline Treatment $+1 \mathrm{mg} . I^{-1} \mathrm{BA}+0.2 \mathrm{mg} . I^{-1} \mathrm{NAA}$ & $4.13^{\mathrm{a}}$ & $8.28^{\mathrm{a}}$ & $6.86^{\mathrm{a}}$ \\
$\mathrm{MS}+1 \mathrm{mg} \mathrm{I}^{-1} \mathrm{BA}+1 \mathrm{mg} . \mathrm{I}^{-1} \mathrm{NAA}$ & $2.54^{\mathrm{b}}$ & $6.03^{\mathrm{b}}$ & $6.46^{\mathrm{a}}$ \\
$\mathrm{MS}+1 \mathrm{mg} .^{-1} \mathrm{BA}+1 \mathrm{mg} . \mathrm{I}^{-1} \mathrm{NAA}$ & $2.02^{\mathrm{b}}$ & $4.32^{\mathrm{c}}$ & $2.76^{\mathrm{b}}$ \\
In vitro rhizome explant & $1.83^{\mathrm{b}}$ & $4.78^{\mathrm{b}}$ & $3.27^{\mathrm{b}}$ \\
In vivo rhizome explant (pot plant) & $3.97^{\mathrm{a}}$ & $7.65^{\mathrm{a}}$ & $7.45^{\mathrm{a}}$ \\
\hline
\end{tabular}

*Means within columns not followed by the same letter are significantly different by Tukey's test at $5 \%$ level.

$\mathrm{M} 1=\mathrm{MS}+1 \mathrm{mg} \cdot \mathrm{I}^{-1} \mathrm{BA}+0.2 \mathrm{mg} \cdot \mathrm{I}^{-1} \mathrm{NAA}$.

$\mathrm{M} 2=\mathrm{MS}+1 \mathrm{mg} \cdot \mathrm{I}^{-1} \mathrm{BA}+1 \mathrm{mg} \cdot \mathrm{I}^{-1} \mathrm{NAA}$.

$\mathrm{M} 3=\mathrm{MS}+1 \mathrm{mg} \cdot \mathrm{I}^{-1} \mathrm{BA}+0.2 \mathrm{mg} \cdot \mathrm{I}^{-1} \mathrm{IAA}$.

$\mathrm{O} 1=$ in vitro rhizome explant.

$\mathrm{O} 2$ = in vivo rhizome explant (pot plant).

\section{Culture initiations}

All of the test tubes were kept in $18 \pm 1{ }^{\circ} \mathrm{C}$ and in photoperiod of 16 h light $(26-30 \mu \mathrm{mol} m-2 \mathrm{~s}-1)$. The materials were subculture 4 times ( 3 weeks intervals) on fresh medium. Finally plantlets were evaluated in according to the number of shoots, rhizomes and roots.

\section{Statistical analysis}

The factorial experiment was arranged in a complete randomized design with 2 factors (culture media at 3 levels and origin of explants at 2 levels), 3 replications and 10 explants per replicate. Before statistical analysis, the normality of data was tested by using MSTATC soft wear and analysis of variance was carried out on normal collected data by SAS soft wear. The mean value of data was compared at $5 \%$ level using Turkey's test.

\section{RESULTS AND DISCUSSION}

\section{Shoot proliferation}

As shown in Table 1, the number of produced shoots (average 4.13) was affected the most by M1 culture medium (Figure 1). In the same concentration of BA (1 $\mathrm{mg} \mathrm{l}-1$ ) shoot proliferation increased in response to 0.2 mg l-1 NAA. Further increase of NAA (1 mg l-1) reduced shoot proliferation to 2.54. Replacing $0.2 \mathrm{mg} \mathrm{I-1} \mathrm{NAA} \mathrm{by}$ $0.2 \mathrm{mg} \mathrm{I}-1$ IAA had shown no significant effect for the above trait. Our finding showed (Table 1) that rhizome buds explants obtained from pot plants (in vivo) could results in higher number of shoot proliferation (3.97) compared with those derived in vitro (1.83). It should be mentioned that although using in vivo rhizome bud with larger size, more nutrition and hormone produced higher number of shoots but shoot regeneration of in vitro explants were more rapidly in less time duration. The main problem on using pot plant rhizome as initial explants was contamination which occurred frequently in cultures and it seems it is difficult to overcome. Analysis of variance showed (table not shown) no significant differences on combining effects of rhizome types and culture media.

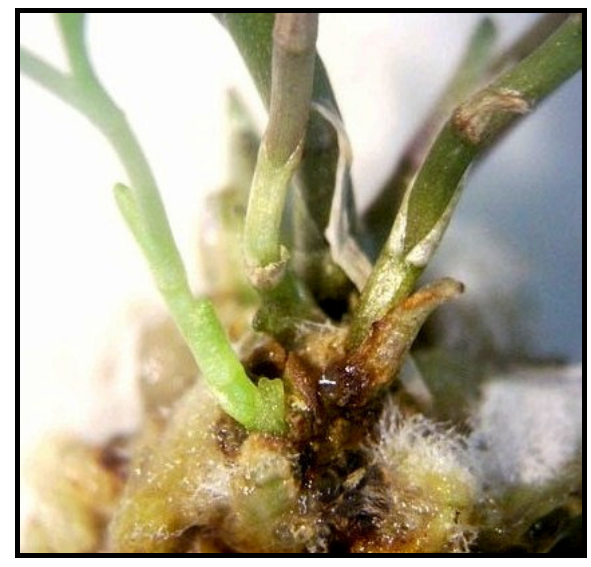

Figure 1. Shoots produced in $\mathrm{M} 1\left(\mathrm{MS}+1 \mathrm{mg} \cdot \mathrm{I}^{-1} \mathrm{BA}+\right.$ $0.2 \mathrm{mg}^{-1} \mathrm{I}^{-1} \mathrm{NAA}$ ) culture medium.

Therefore, the mean value of this trait was not calculated.

The results obtained in this section are in accordance with the ones obtained in Han et al. (1994) study in terms of having more affect in case of using a combinations of $\mathrm{BA}$ and low level concentration of NAA in comparison with using BA alone in micropropagation of rhizome buds. These results, however, differ from those obtained by Pierik et al. (1997) who reported that auxin has no effect on shoots growing.

\section{Rhizome production}

Rhizome production was enhanced by using $0.2 \mathrm{mg} \mathrm{l}-1$ NAA (Table 1). The number of resultant rhizomes was high and significantly decreased in response to increasing NAA concentration or replacing NAA by $0.2 \mathrm{mg} \mathrm{l}-1$ IAA. The highest number of rhizome, 8.28 rhizomes per explants, was obtained on medium containing $0.2 \mathrm{mg} \mathrm{l-1}$ NAA (Figure 2). In addition, rhizome production on in vivo derived explants was significantly higher than those derived from in vitro grown rhizome as primary explants. 
Table 2. Interaction effects of culture media and rhizome types on number of shoots, rhizomes and roots.

\begin{tabular}{|c|c|c|c|c|c|c|}
\hline & \multicolumn{2}{|c|}{ Number of shoots } & \multicolumn{2}{c|}{ Number of rhizomes } & \multicolumn{2}{c|}{ Number of roots } \\
\cline { 2 - 7 } Media & $\begin{array}{c}\text { in vitro } \\
\text { explant }\end{array}$ & $\begin{array}{c}\text { In vivo } \\
\text { explant }\end{array}$ & $\begin{array}{c}\text { in vitro } \\
\text { explant }\end{array}$ & $\begin{array}{c}\text { In vivo } \\
\text { explant }\end{array}$ & $\begin{array}{c}\text { in vitro } \\
\text { explant }\end{array}$ & $\begin{array}{c}\text { In vivo } \\
\text { explant }\end{array}$ \\
\hline $\mathrm{MS}+1 \mathrm{mg} \cdot \mathrm{I}^{-1} \mathrm{BA}+0.2 \mathrm{mg} \cdot \mathrm{I}^{-1} \mathrm{NAA}$ & 3.07 & 4.88 & $5.92^{\mathrm{bc}}$ & $10.65^{\mathrm{a}}$ & $3.52^{\mathrm{c}}$ & $10.20^{\mathrm{a}}$ \\
$\mathrm{MS}+1 \mathrm{mg} \cdot \mathrm{I}^{-1} \mathrm{BA}+1 \mathrm{mg} \cdot \mathrm{I}^{-1} \mathrm{NAA}$ & 3.57 & 2.80 & $4.80^{\mathrm{cd}}$ & $7.26^{\mathrm{b}}$ & $4.07^{\mathrm{c}}$ & $8.84^{\mathrm{b}}$ \\
$\mathrm{MS}+1 \mathrm{mg} \cdot \mathrm{I}^{-1} \mathrm{BA}+0.2 \mathrm{mg} \cdot \mathrm{I}^{-1} \mathrm{AA}$ & 3.13 & 2.68 & $3.61^{\mathrm{d}}$ & $5.03^{\mathrm{cd}}$ & $2.21^{\mathrm{d}}$ & $3.31^{\mathrm{cd}}$ \\
\hline
\end{tabular}

*Means within columns not followed by the same letter are significantly different by Tukey's test at $5 \%$ level.

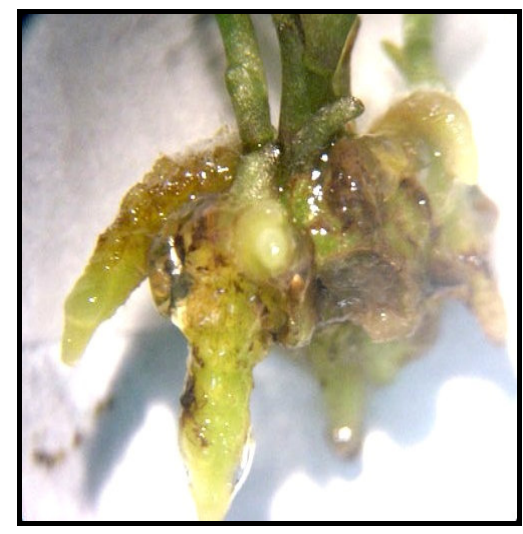

Figure 2. Rhizomes produced from in vivo explant in $\mathrm{M} 1$ (MS + 1mg. $\left.\mathrm{I}^{-1} \mathrm{BA}+0.2 \mathrm{mg} . \mathrm{l}^{-1} \mathrm{NAA}\right)$ culture medium.

Mean comparison of rhizome types and media showed (Table 2) that in vivo derived rhizome on M1 culture medium resulted in the most number of rhizomes (10.65). Low number of rhizome obtained with in vitro explants and $\mathrm{M} 3$ culture media containing $0.2 \mathrm{mg} \mathrm{I} 1$ IAA. Han et al. (1994) obtained the highest level of multiplication of rhizome in MS culture medium with 1 - $2 \mathrm{mg} \mathrm{I-1} \mathrm{BA} \mathrm{and}$ $0.2 \mathrm{mg} \mathrm{l}-1$ NAA and their results are similar to ours.

\section{Number of roots}

According to our results (Table 1), higher number of roots was obtained with significant differences on M1 (6.86) and M2 (6.46) culture media in comparison with M3 (2.76). In addition, in vivo derived explants showed significant effect on root production with an average 7.45 roots per explants. Comparing all treatments (Table 2), the highest number of roots (10.20) was obtained by using in vivo rhizome explants in the presence of $0.2 \mathrm{mg}$ I-1 NAA. This result is similar to that of Podwyszynska et al. (1998) who reported that applied NAA in culture medium strongly stimulated formation of root.

\section{Conclusion}

In the present study, incorporation of $0.2 \mathrm{mg} \mathrm{I-1} \mathrm{NAA} \mathrm{to}$ the culture medium resulted in more shoots, number of rhizomes and roots. The combination of $0.2 \mathrm{mg} \mathrm{l}-1$ NAA and pot plant derived rhizome showed a synergistic effect in improving number of rhizomes and roots. Such synergistic interaction has been observed to promote shoot proliferation. The best medium was the combination of MS basal medium with $0.2 \mathrm{mg} \mathrm{I-1} \mathrm{NAA} \mathrm{and} 1 \mathrm{mg} \mathrm{I-}$ $1 \mathrm{BA}$. When grown on the best selected medium, a single bud rhizome derived from pot plant, could produce 5.20 , 10.65 and 10.20 shoots, rhizomes and roots, respectively. Although, in vivo derived rhizomes compared with in vitro rhizomes showed higher number of rhizomes, the more laborious and high contamination of explants during sterilization and culture favors the use of in vitro explants.

\section{REFERENCES}

Bond S, Alderson PG (1993). The influence of apical dominance on the in vitro multiplication of the rhizome of Alstroemeria. J. Hortic. Sci. 68:905-910.

Chiari A, Bridgen MP (2000). Rhizome spiliting: a new micropropagation technique to increase in vitro propagula yield in Alstroemeria. Plant Cell Tissue Org. Cult. 62: 39-46.

Gabryszewska E, Hemple M (1985). The influence of cytokinins and auxins on Alstroemeria in tissue culture. Acta Hortic.167: 295-300.

Hakkaart FA, Versluijs JMA (1988). Virus elimination by meristem tip culture from arrange of Alstroemeria cultivars. Neth. Plant Pathol. 94:49-56.

Han BH, Kim YJ, Choi JK (1994). Micropropagation of Alstroemeria. throught rhizome bud culture. J. Korean Soc. Hortic. Sci. 35: 172 177.

Lin HS, Monette PL (1987). In vitro propagation of Alstroemeria 'Alsaan`. Plant Cell Tissue Org. Cult. 9: 29-35.

Murashige T, Skoog F (1962). A revised medium for rapid growth and bio-assay with tobacco tissue culture. Physiol. Plant. 15: 473-497.

Pierik RL, Voorst A, Boody G, Acker CAM, Lelivelt CLC, Wit JC (1997). Vegetative propagation of Alstroemeria Hybrids in vitro. Acta Hortic. 226: 143-147.

Podwyszynska M, Gabryszewska E, Przybyla A (1998). Effect of growth retardants, cytokinins and auxins on the multiplication and rooting in vitro of Alstroemeria X hybrida 'Juanita'. Acta Agron. 51: 23-31.

Van Zaayen C, Van E, Versluijs JMA (1992). Production of high quality, healthy ornamental crops through meristem culture. Acta Bot. Neerl., 41: 425-433. 